\title{
Systematic review of the association between Alzheimer's disease and chronic glaucoma
}

This article was published in the following Dove Press journal:

Clinical Ophthalmology

4 May 2015

Number of times this article has been viewed

Sarah F Janssen'

Nomdo M Jansonius ${ }^{2}$

Femke Bouwman ${ }^{3}$

Frank D Verbraak ${ }^{1,4}$

Arthur A Bergen ${ }^{5}$

'Department of Ophthalmology, VU Medical Center, Amsterdam;

${ }^{2}$ Department of Ophthalmology,

University of Groningen, University

Medical Center Groningen,

Groningen; ${ }^{3}$ Alzheimer Center, VU

Medical Center, ${ }^{4}$ Department of

Ophthalmology, ${ }^{5}$ Department of

Clinical Genetics, Academic Medical

Center, Amsterdam, the Netherlands

\section{Dear editor}

We read with great interest the paper by Tsilis et al entitled "Systematic review of the association between Alzheimer's disease and chronic glaucoma" published recently in this journal. ${ }^{1}$ The potential overlap in the pathobiological background of Alzheimer's disease $(\mathrm{AD})$ and primary open angle glaucoma (POAG) is currently a topic of intense discussion and could provide further insight into both of these complex diseases.

Last year, we published an extensive review on POAG and the potential link between $\mathrm{AD}$ and POAG. ${ }^{2}$ Both $\mathrm{AD}$ and POAG consist of several clinical subtypes, and are genetically heterogeneous disorders. In our POAG disease model, we found that at least 65 candidate disease genes, together defining several molecular mechanisms (developmental dysfunction, lipid metabolism, and inflammatory processes), underlie the disease. ${ }^{2}$ For $\mathrm{AD}$, at least 31 genes have been associated with the disease. ${ }^{3}$ We also showed that, on a molecular level, there is overlap between the molecular mechanisms of POAG and those of AD. ${ }^{4}$

When comparing two (genetically) heterogeneous disease entities, the conclusion that high heterogeneity and nonassociation will be found seems obvious. The study by Cumurcu et $\mathrm{al}^{5}$ cited by Tsilis et al, concerns a very distinct form of glaucoma, ie, pseudoexfoliation glaucoma, caused uniquely by mutations in the LOXL1 gene, ${ }^{6}$ and AD. We believe that this study should be considered separately, or pooled with data from other pseudoexfoliation glaucoma (and AD) studies. The data from this study cannot be extrapolated to others.

We agree with Tsili et al that large and high-quality association studies, preferably with long follow-up, are needed to clarify the existence and nature of possible associations between POAG and AD. However, at the same time, these studies will only be useful if specific clinical or genetic subtypes of glaucoma and AD are considered. In this respect, we proposed to investigate the existence of a possible association between normal tension glaucoma and $\mathrm{AD} .^{2}$

\section{Disclosure}

The authors report no conflicts of interest in this work.

\section{References}

1. Tsilis AG, Tsilidis KK, Pelidou SH, Kitsos G. Systemic review of the association between Alzheimer's disease and chronic glaucoma. Clin Ophthalmol. 2014;8:2095-2104.

2. Janssen SF, Gorgels TG, Ramdas WD, et al. The vast complexity of primary open angle glaucoma: disease genes, risks, molecular mechanisms and pathobiology. Prog Retin Eye Res. 2013;37: $31-67$. 
3. Karch CM, Cruchaga C, Goate AM. Alzheimer's disease genetics: from the bench to the clinic. Neuron. 2014;83:11-26.

4. Janssen SF, Gorgels TG, Ramdas WD, et al. Alzheimer's disease and glaucoma - reply. Prog Retin Eye Res. 2014;39:108-110.

5. Cumurcu T, Dorak F, Cumurcu BE, Erbay LG, Ozsoy E. Is there any relation between pseudoexfoliation syndrome and Alzheimer's type dementia? Semin Ophthalmol. 2013;28:224-229.
6. Thorleifsson G, Magnusson KP, Sulem P, et al. Common sequence variants in the LOXL1 gene confer susceptibility to exfoliation glaucoma. Science. 2002;317:1397-1400.

\section{Publish your work in this journal}

Clinical Ophthalmology is an international, peer-reviewed journal covering all subspecialties within ophthalmology. Key topics include: Optometry; Visual science; Pharmacology and drug therapy in eye diseases; Basic Sciences; Primary and Secondary eye care; Patient Safety and Quality of Care Improvements. This journal is indexed on

\section{Dovepress}

PubMed Central and CAS, and is the official journal of The Society of Clinical Ophthalmology (SCO). The manuscript management system is completely online and includes a very quick and fair peer-review system, which is all easy to use. Visit http://www.dovepress.com/ testimonials.php to read real quotes from published authors. 